\title{
Independensi, Integritas, Serta Kompetensi Auditor Terhadap Kualitas Audit dengan Skeptisisme Profesional Sebagai Variabel Pemoderasi
}

\section{Independence, Integrity and Auditor Competence Against Audit Quality with Professional Skepticism as a Moderating Variable.}

Rizky Darmawan Santoso*, Ikhsan Budi Riharjo, Kurnia

STIESIA Surabaya, Indonesia

The purpose of this study is to determine the effect of independence, integrity and competence on audit quality and find out if it is proven that professional skepticism is able to moderate the effect of independence, integrity, competence, respectively on audit quality. The data collection method used is by distributing questionnaires to all public accounting firms (KAP) in the city of Surabaya. The sample selection technique uses a purposive sampling technique with KAP auditors as research subjects. The results showed that the

OPEN ACCESS ISSN 2548-3501 (online)

Edited by:

Eny Maryanti

Reviewed by:

Dwi Suhartini

${ }^{*}$ Correspondence:

Rizky Darmawan Santoso

24rizky24@gmail.com

Received: 4 Juni 2020

Accepted: 02 Juli 2020

Published: 31 Juli 2020

Citation:

Santoso $R D$, Riharjo IB and $\mathrm{K}$ (2020) Independensi, Integritas, Serta Kompetensi Auditor Terhadap Kualitas Audit dengan Skeptisisme

Profesional Sebagai Variabel Pemoderasi.

Journal of accounting Science. 4:2. doi: 10.21070/jas.v4i2.559 higher the independence, integrity and competence, the better the audit quality would be. The moderating variable professional skepticism is able to moderate the positive influence of independence on audit quality, and negatively moderate the effect of integrity on audit quality but is not able to moderate the effect of competence on audit quality.

Keywords: Independence, Integrity, Competence, Professional Skepticism, Audit Quality

Tujuan penelitian ini adalah untuk mengetahui pengaruh independensi, integritas, dan kompetensi terhadap kualitas audit dan untuk mengetahui apakah skeptisisme profesional terbukti mampu memoderasi pengaruh independensi, integritas, kompetensi masing-masing terhadap kualitas audit. Metode yang digunakan adalah dengan menyebarkan kuesioner kepada seluruh Kantor Akuntan Publik (KAP) yang ada di kota Surabaya. Teknik pemilihan sampel menggunakan teknik purposive sampling dengan subjek penelitian auditor KAP. Hasil penelitian menunjukkan bahwa semakin tinggi independensi, integritas dan kompetensi maka kualitas auditnya akan semakin baik. Variabel moderasi skeptisisme profesional mampu memoderasi pengaruh positif independensi terhadap kualitas audit, dan secara negatif memoderasi pengaruh integritas terhadap kualitas audit tetapi tidak mampu memoderasi pengaruh kompetensi terhadap kualitas audit. 
Keywords: Independensi, Integritas, Kompetensi, Skeptisisme Profesional, Kualitas Audit 


\section{PENDAHULUAN}

Kualitas audit yang dihasilkan auditor dapat dipengaruhi beberapa faktor antara lain independensi, integritas, kompetensi dan sikap mental skeptisisme. Jasa audit yang ditawarkan oleh Kantor Akuntan Publik (KAP) dapat dikatakan sebagai usaha kepercayaan. Artinya dari kepercayaan klien/masyarakat yang menarik minatnya untuk menggunakan jasa sebuah KAP. Lebih dari 30 KAP di Surabaya yang terdaftar menurut Otoritas Jasa Keuangan (OJK) membuat persaingan antarKAP menjadi ketat untuk memenangkan hati masyarakat. Merupakan hal yang lumrah bagi KAP untuk menjaga citra atau nama baiknya yang dimaksudkan agar menjaga kredibilitasnya di mata publik. Dengan kepercayaan masyarakat akan KAP maka diikuti dengan tanggung jawab tinggi atas kepercayaan tersebut.

Meninjau dari kasus perusahaan burung terbang terkemuka di Indonesia, PT Garuda Indonesia, Tbk yang di muat www.economy.okezone.com tahun 2019 sebagai berikut: "Berawal dari hasil laporan keuangan Garuda Indonesia untuk tahun buku 2018. Dalam laporan keuangan tersebut, Garuda Indonesia Group membukukan laba bersih sebesar USD809,85 ribu atau setara Rp11,33 miliar (kurs Rp14.000 per dolar AS). Angka ini melonjak tajam dibanding 2017 yang menderita rugi USD216,5 juta. Namun laporan keuangan tersebut menimbulkan polemik, lantaran dua komisaris Garuda Indonesia yakni Chairal Tanjung dan Dony Oskaria (saat ini sudah tidak menjabat), menganggap laporan keuangan 2018 Garuda Indonesia tidak sesuai dengan PSAK. Pasalnya, Garuda Indonesia memasukan keuntungan dari PT Mahata Aero Teknologi yang memiliki utang kepada maskapai berpelat merah tersebut. PT Mahata Aero Teknologi sendiri memiliki utang terkait pemasangan wifi yang belum dibayarkan.

Kemenkeu tim Pusat Pembinaan Profesi Keuangan (PPPK) menetapkan sanksi berupa pembekuan izin selama 12 bulan pada Kasner Sirumapea yang berlaku sejak 27 Juli 2019. Sementara itu, untuk KAP dikenakan Peringatan Tertulis dengan disertai kewajiban untuk melakukan perbaikan terhadap Sistem Pengendalian Mutu KAP dan dilakukan tinjauan oleh BDO International Limited." (https://economy.okezone.com/ $\mathrm{read} / 2019 / 06 / 28 / 320 / 2072154 /$ kasus-garuda-pembekuan-izin -auditor-laporan-keuangan-berlaku-27-juli-2019? page $=1$ ).

Dari kasus di atas memunculkan berbagai asumsi dari masyarakat termasuk peneliti. Ikhwal yang paling disoroti yaitu terkait kode etik dari segi independensi, integritas, dan juga kompetensi auditor terkait. Kasner selaku auditor dengan jelas melakukan pelanggaran secara tidak tepat menilai kontrak yang sekian puluh tahun sebagai piutang namun diakui sebagai pendapatan sekaligus di awal. Hal ini jelas diragukan dari hal indepenensi apakah sang auditor benarbenar melakukannya sendirian, atau justru dengan bekerja sama bersama pihak tertentu. Selain itu integritas yang merupakan kejujuran juga diragukan ketika melihat jam terbang seorang Akuntan Publik senior ini yang telah bergabung seba- gai anggota BDO pada tahun 2012. Kompetensi sebagai tonggak pekerjaan seorang akuntan publik dipertanyakan. Jika memang pelanggaran Standar Audit yang dilakukan Kasnir merupakan hal yang tidak disengaja, lalu bagaimana level kompetensi pada beliau sehingga salah memperlakukan metode akuntansi. Beberapa kode etik yang telah disebutkan di atas bermuara mempengaruhi kualitas audit. Kualitas audit yang baik ketika auditor mampu menerapkan kode etik profesi sesuai aturan yang telah diterbitkan oleh IAPI.

Dilatarbelakangi oleh pentingnya mentaati kode etik profesi akuntan publik, mengarahkan penelitian pengaruh dari independensi, integritas serta kompetensi terhadap kualitas audit dengan skeptisisme sebagai variabel moderasinya. Namun terdapat beberapa penelitian terdahulu yang memberi hasil tidak signifikan seperti pada penelitian terdahulu oleh Febrianti (2014) dengan hasil independensi tidak berpengaruh terhadap kualitas audit. Sukriah et al. (2009) menghasilkan integritas tidak berpengaruh terhadap kualitas audit. Susanti and Tarigan (2013) kompetensi tidak berpengaruh terhadap kualitas audit. Gap penelitian tersebut tentunya menjadi arwah dalam penelitian ini sebagai pembuktian apakah kualitas audit ditentukan oleh variabel bebas yang telah dicanangkan peneliti seperti independensi, integritas, kompetensi audit.

Teori Behavior adalah sebuah teori yang dicetuskan oleh Gage dan Berliner tentang perubahan tingkah laku sebagai hasil dari pengalaman Sendjaja (2004). Behaviorisme ingin menganalisis bahwa perilaku yang tampak saja yang dapat diukur, dilukiskan, dan diramalkan. Behaviorisme mengasumsikan ketika dilahirkan manusia tidak membawa bakat apaapa. Pada fase berikutnya manusia mengalami perkembangan di mana perkembangan tersebut disebabkan oleh stimulus yang diterima seseorang dari lingkungan sekitar.Proses perubahan sikap menurut Hovland, Janis dan Kelley (1953) dalam Sendjaja (2004) terdapat tiga fase, dimulai dari perhatian, pengertian, hingga penerimaan. Audit dikatakan berkualitas ketika tingkat independensi, integritas, kompetensi, skeptisisme tinggi. Untuk meningkatkan independensi, integritas, kompetensi, serta skeptisisme, dibutuhkan stimulus sesuai dengan teori behavior, di mana seseorang bergerak didasarkan stimulus atau rangsangan sebagai pemicu.

Kualitas audit merupakan karakteristik atau gambaran praktik dan hasil audit berdasarkan standar auditing dan standar pengendalian mutu yang menjadi ukuran pelaksanaan tugas dan tanggung jawab profesi seorang auditor Tandiontong (2016); Febrianti (2014) Sari (2011). Skeptisisme profesional adalah sikap yang mencakup pikiran yang selalu bertanya/tidak mudah puas dengan hal yang belum jelas, waspada dengan kondisi yang mengindikasikan kemungkinan salah saji karena kesalahan atau kecurangan dan penilaian kritis atas bukti audit tanpa obsesif mencurigakan atau skeptisisme. Auditor berkewajiban untuk menggunakan dan mempertahankan skeptisisme profesional, sepanjang periode penugasan. Auditor tidak boleh mengasumsikan bahwa manajemen jujur atau tidak jujur. Tuanakotta (2013) Indonesia (2016) 
Independensi adalah sikap seseorang yang mampu berpegang pada pendiriannya yang tidak tunduk pada kepentingan pribadi maupun kepentingan pihak lain yang berusaha untuk menekan. Auditor tidak boleh berkompromi dalam memberikan pertimbangan profesionalnya karena kepentingan tertentu. Hal tersebut mengarahkan auditor untuk bersikap objektif dalam pekerjaan audit yang dilakukan dan melaporkan hasil audit dengan tingkat independensi yang tinggi. Agoes and C (2009) Herry (2010) Suhayati and Rahayu (2010) . Dengan adanya independensi, maka akan mempengaruhi kualitas audit karena auditor melaksanakan tugasnya baik sisi teknis maupun non teknis secara objektif tanpa ada benturan kepentingan apapun. Hal ini memberikan poin tambahan guna meningkatkan kualitas audit yang dihasilkan. Integritas merupakan sikap tegas yang dimiliki seseorang yang mewujudkan apa yang menjadi komitmennya dalam hal tanggung jawab dan kejujuran ke dalam kenyataan. Auditor yang berintegritas adalah auditor yang memiliki nilai-nilai kejujuran dan mampu mengemukakan keadaan yang sebenarnya terjadi. Indonesia (2016) Sulaiman (2010) . Integritas menomorsatukan kejujuran meskipun dapat menyakiti hati rekan kerja, artinya auditor yang berintegritas mampu bertindak dengan terus terang agar memberi peningkatan dalam kualitas audit yang dihasilkan. Sebaliknya, jika auditor menutup-nutupi hal yang seharusnya dibuka menurut peraturan yang berlaku, maka akan dapat menurunkan kualitas audit bahkan memberikan dampak yang lebih besar lagi seperti tuntutan hukum di kemudian hari.

Kompetensi berarti auditor harus menjaga pengetahuan dan keahlian profesional mereka dalam tingkat yang cukup tinggi dan tekun dalam Febrianti (2014) mengimplementasikan pengetahuan dan keahlian mereka ketika memberikan jasa profesional Tuanakotta (2013) Indonesia (2016) . Kompetensi menurut Mulyadi (2017) diperoleh melalui pendidikan dan pengalaman. Setiap auditor harus melakukan audit dengan tingkat kewaspadaan, menghindari tindakan ceroboh, menggunakan kompetensi semaksimal mungkin, tekun dan konsisten serta memastikan jasa yang diberikan pada klien dilakukan dengan segenap kompetensi yang memadai sehingga meningkatkan kepercayaan akan kualitas jasa yang diberikan serta meningkatkan kredibilitas baik akuntan maupun KAP pemberi jasa. Kompetensi merupakan salah satu nyawa dari sikap seorang auditor, auditor yang tidak berkompeten dapat berdampak luas mulai dari salah tafsir Standar Audit hingga tidak dapat mendeteksi kecurangan yang dilakukan klien sehingga opini yang diterbitkan menjadi tidak valid. Hal ini jelas menurunkan kualitas audit. Dengan ditambahkannya mental skeptis, maka diharapkan kompetensi semakin kuat dalam mempengaruhi kualitas audit. Skeptisisme profesional memberikan seseorang menjadi tidak mudah puas, jika dikaitkan dengan kompetensi, maka auditor tidak akan puas sehingga terus memelihara kompetensinya dengan berbagai cara salah satunya dengan mengikuti sosialisasi perkembangan peraturan audit menurut Standar Audit, kode etik, dan lain-lain yang berkaitan dengan bidang audit.
Tujuan penelitian ini untuk mengetahui hubungan independensi, integritas, kompetensi auditor, skeptisisme professional terhadap kualitas audit dan untuk mengetahui pengaruh skeptisisme sebagai variabel moderasi.

\section{METODE PENELITIAN}

\section{Jenis dan Pendekatan Penelitian}

Penelitian ini menggunakan metode kuantitatif yang berlandaskan pada filsafat positivisme Sugiyono (2018) . Penelitian ini terdiri dari lima variabel yaitu Integritas (Int) yang merupakan sikap tegas, jujur serta mampu berterus terang demi tanggung jawab dalam diri, Independensi (Ind) yaitu sikap seseorang yang mampu berpegang pada pendiriannya yang tidak tunduk pada kepentingan pribadi maupun kepentingan pihak lain yang berusaha untuk menekan, Kompetensi (Kom) yaitu keahlian teknis yang dimiliki seseorang, Skeptisisme Profesional (Skep) merupakan sikap waspada dan curiga secara profesional serta hati-hati guna hingga ke tingkat kepercayaan tertentu, dan Kualitas Audit (KA) yang merupakan karakteristik atau gambaran praktik dan hasil audit berdasarkan standar auditing dan standar pengendalian mutu yang menjadi ukuran pelaksanaan tugas dan tanggung jawab profesi seorang auditor.

\section{Lokasi Penelitian}

Penelitian ini dilakukan pada Kantor Akuntan Publik (KAP) di Kota Surabaya. Adapun objek penelitian yaitu auditor KAP di Surabaya.

\section{Sumber Data}

Sumber data yang digunakan adalah data primer berupa kuesioner dengan skala likert sebagai poinnya.

\section{Populasi dan Sampel}

Penelitian ini menggunakan teknik purposive sampling yaitu dilakukan dengan mengambil sampel dari populasi berdasarkan suatu kriteria tertentu Hartono (2013). Arikunto (2014) menyebutkan bahwa pengambilan sampel dengan teknik bertujuan ini cukup baik karena sesuai dengan pertimbangan peneliti sendiri sehingga dapat mewakili populasi. Adapun sampel yang akan dipilih yaitu dengan kriteria sebagai berikut:

1. Karyawan di bagian divisi audit.

2. Menjabat sebagai Senior dan Junior auditor.

Alasan peneliti memberi kriteria yang pertama karena terkait topik audit sehingga subjek yang diteliti yaitu auditor di KAP. Sedangkan kriteria kedua, jabatan senior dan junior auditor dijadikan sampel karena kedua jabatan ini yang melakukan audit langsung di lapangan sehingga banyak memainkan peran dalam menjalankan kode etik serta standar teknis audit yang belaku. 


\section{Teknik Pengumpulan Data}

Teknik pengumpulan data dalam penelitian ini adalah dengan menyebarkan kuesioner kepada sampel yang telah ditetapkan. Pengukuran variabel dalam penelitian ini menggunakan skala skala Likert Malhotra (2005)

\section{Uji Validitas dan Reliabilitas}

Uji validitas menunjukkan sejauh mana suatu alat pengukur dapat mengukur apa yang ingin diukur. Setelah dilakukan pengujian validitas pada SPSS, apabila diperoleh $r$ hitung lebih besar dari $r$ tabel, maka pernyataan tersebut dinyatakan valid. Sedangkan reliabilitas adalah tingkat ketepatan, ketelitian, atau keakuratan instrumen yang digunakan dalam sebuah penelitian Hasan (2002) . Dalam penelitian ini, teknik pengukuran reliabilitas yang digunakan adalah teknik Cronbach Alpha. Suatu alat ukur dinyatakan realibel jika nilai alpha untuk setiap pernyataan lebih besar dari 0,6 Sujarweni (2014) .

\section{Teknik Analisis Data}

Teknik yang digunakan dalam penelitian ini adalah analisis regresi linear berganda dan Moderated Regression Analysis(MRA).

\section{Uji Asumsi Klasik}

Uji asumsi klasik dilakukan untuk mengetahui apakah parameter yang dihasilkan bersifat BLUE (Best Linear Unbiased Estimation), artinya koefisien regresi pada persamaan tersebut tidak terjadi penyimpangan-penyimpangan sehingga penelitian dapat dilanjutkan. Uji asumsi klasik dalam penelitian ini terdiri dari uji normalitas, multikolonieritas serta heterokedastisitas.

\section{Uji Hipotesis}

Uji $F$

Uji F dilakukan untuk menguji apakah model dalam penelitian ini dikatakan layak.

\section{Uji t}

Uji t dilakukan untuk menetukan apakah variabel-variabel bebas yang terdiri independensi, integritas, kompetensi mempunyai pengaruh yang signifikan terhadap variabel terikat yaitu kualitas audit. Ghozali (2011) .

\section{HASIL DAN PEMBAHASAN}

\section{Gambaran Umum Objek Penelitian}

Penelitian dilakukan menggunakan kuesioner yang disebar pada Kantor Akuntan Publik (KAP) di Surabaya. Objek penelitian yaitu auditor KAP yang menjabat sebagai Senior dan Junior Auditor. Adapun jumlah KAP di Surabaya sebanyak 43
KAP. Dengan jumlah 129 responden, jenis kelamin laki-laki 83 orang, perempuan 46 orang dengan latar belakang pendidikan S1 sebanyak 111 orang dan sisanya 18 orang D3.

[Table 1 about here.]

Dari Tabel 1 nilai koefisien reliabilitas cronbach alpha tersebut nilainya lebih dari atau di atas 0,6 maka dapat disimpulkan bahwa instrumen atau kuesioner disebar ke 129 responden reliabel sehingga dapat dilanjutkan dalam penelitian.

[Table 2 about here.]

Dari Tabel 2 hasil uji validitas diperoleh $\mathbf{r}_{\text {hitung }}$ dalam instrumen penelitian yang digunakan semuanya mempunyai nilai yang lebih besar atau berada di atas nilai kritis $\left(\mathrm{r}_{\text {tabel }}\right)$, sehingga dapat disimpulkan bahwa indikator pada instrumen penelitian sudah valid sehingga dapat dilanjutkan untuk penelitian selanjutnya.

\section{Uji Asumsi Klasik Uji Normalitas}

[Table 3 about here.]

Tabel 3 Pada tabel di atas memperlihatkan bahwa Asymp. Sig. (2-tailed) sebesar 0,200. Artinya data berdistribusi normal lebih dari 0,05. Dengan demikian dapat disimpulkan bahwa penyebaran data dalam model regresi memenuhi asumsi normalitas.

[Table 4 about here.]

Tabel 4 di atas menunjukkan bahwa seluruh variabel bebas dan moderasi yang digunakan dalam penelitian ini mempunyai nilai VIF (Variance Inflation Factor) $<10$ dan nilai tolerance $>0,1$ maka hal ini berarti dalam persamaan regresi tidak ditemukan adanya korelasi antarvariabel bebas atau bebas multikolonieritas, sehingga seluruh variabel bebas tersebut dapat digunakan dalam penelitian.

\section{Uji Heterokedastisitas}

[Figure 1 about here.]

Dari Gambar 1 gambar di atas terlihat bahwa titik-titik menyebar secara acak serta tersebar baik di atas maupun dibawah angka 0 pada sumbu Y. Hal ini disimpulkan bahwa tidak terjadi heteroskedastisitas pada model regresi. Dengan demikian asumsi non heteroskedastisias terpenuhi.

\section{Analisis Statistik Deskriptif}

Berikut merupakan tabel hasil analisis deskriptif dari variabel penelitian dari nilai minimum, nilai maksimum, rata-rata, dan standar deviasi.

[Table 5 about here.] 


\section{Hasil Uji Hipotesis}

\section{Hasil Uji F pada Model Regresi 1}

[Table 6 about here.]

Hasil signifikansi sebesar 0,000 menunjukkan bahwa model regresi 1 layak untuk digunakan dalam penelitian.

\section{Hasil Uji F pada Model Regresi 2}

[Table 7 about here.]

Hasil signifikansi sebesar 0,000 pada Tabel 7 menunjukkan bahwa model regresi 2 layak untuk digunakan dalam penelitian.

\section{Hasil Uji t Model Regresi 1}

[Table 8 about here.]

Model regresi 1 pada Tabel 8 merupakan hasil dari regresi linier berganda yang menguji pengaruh variabel bebas terhadap variabel terikat.

\section{Hasil Uji t Model Regresi 2}

[Table 9 about here.]

Model regresi 2 pada Tabel 9 merupakan model regresi moderasi di mana terdapat variabel interaksi di dalamnya seperti independensi berinteraksi dengan skeptisisme, integritas, dan kompetensi.

\section{PEMBAHASAN HIPOTESIS}

\section{Pengaruh Independensi terhadap Kualitas Audit pada KAP di Surabaya.}

Berdasarkan uji t dengan nilai signifikansi 0,000, maka nilai signifikansi tersebut lebih kecil dari taraf signifikansi 0,05, dapat disimpulkan bahwa variabel independensi terbukti mempunyai pengaruh positif terhadap kualitas audit pada KAP di Surabaya. Teori behavior menjadi dasar penyerapan awal auditor dalam menanggapi regulasi Standar Audit. Dalam hal ini Standar Audit menjadi stimulus yang merangsang auditor untuk melakukan sikap independensinya.

Sikap independensi menunjukkan perilaku yang netral ketika menjalankan audit, tidak memihak serta tidak di bawah pengaruh atau tekanan pihak tertentu dalam mengambil keputusan dan tindakan. Semakin tinggi tingkat independensi seorang auditor, maka berpengaruh positif terhadap kualitas audit. Independensi menurut Kode Etik dibagi menjadi dua yaitu independensi dalam pemikiran dan independensi dalam penampilan. Independensi dalam pemikiran berarti auditor menjaga sikap mental yang memungkinkan pernyataan pemikiran yang tidak dipengaruhi oleh hal-hal yang dapat mempengaruhi pertimbangan profesional auditor. Sedangkan independensi dalam penampilan yaitu sikap menghindari tindakan atau situasi yang dapat menyebabkan pihak ketiga meragukan independensi auditor tersebut. Dalam kasus auditor yang sengaja bekerja sama dengan klien untuk melakukan kecurangan pada laporan keuangan, maka auditor tersebut tidak bersikap independen, begitu juga jika terdapat hubungan khusus atau luar biasa dengan klien maka independensi auditor diragukan. Sejalan dengan Agusti and Pertiwi (2013) , Karnia and Haryanto (2015), Gita and Dwirandra (2018) bahwa independensi berpengaruh positif terhadap kualitas audit.

\section{Pengaruh Integritas terhadap Kualitas Audit pada KAP di Surabaya.}

Berdasarkan uji t dengan nilai signifikansi 0.034, maka nilai signifikansi tersebut lebih kecil dari taraf signifikansi 0.05 , maka dapat disimpulkan bahwa variabel integritas terbukti mempunyai pengaruh signifikan terhadap kualitas audit pada KAP di Surabaya. Uji signifikansi ini hampir mendekati 0.05 namun yang kita jadikan acuan karena nilainya di bawah 5\% tersebut sehingga tetap dikatakan signifikan. Di dalam Kode Etik diatur bahwa setiap praktisi harus tegas dan jujur dalam menjalin hubungan profesional dan hubungan bisnis dalam melaksanakan pekerjaannya. Integritas mengharuskan auditor untuk bersikap jujur dan berterus terang tanpa mengorbankan rahasia penerima jasa. Artinya auditor yang berintegritas tetap menjaga rahasia klien sebagai penerima jasa. Integritas diukur dalam bentuk apa yang benar dan adil. Pentingnya integritas diperkuat oleh Sulaiman (2010) bahwa integritas dapat menerima kesalahan yang tidak disengaja dan perbedaan pendapat yang jujur, tetapi tidak dapat menerima kecurangan atau peniadaan prinsip.

Teori behavior menjadi dasar penyerapan awal auditor dalam menanggapi regulasi Standar Audit. Dalam hal ini Standar Audit menjadi stimulus yang merangsang auditor untuk melakukan sikap integritasnya. Integritas seorang auditor ditunjukkan dengan kemampuan mewujudkan yang telah diyakini kebenarannya tersebut ke dalam kenyataan dengan nilai-nilai kejujuran. Integritas mempengaruhi kualitas audit di mana semakin tinggi integritas auditor maka semakin berkualitas audit yang dihasilkan. Hasil penelitian ini didukung oleh penelitian sebelumnya yang dilakukan oleh Susilo and Widyastuti (2015) serta Gita and Dwirandra (2018) bahwa integritas berpengaruh positif terhadap kualitas audit.

\section{Pengaruh Kompetensi Auditor terhadap Kualitas Audit pada KAP di Surabaya.}

Berdasarkan uji t dengan nilai signifikansi 0,000, maka nilai signifikansi tersebut lebih kecil dari taraf signifikansi 0,05, dapat disimpulkan bahwa variabel kompetensi terbukti mempunyai pengaruh signifikan terhadap kualitas audit pada KAP di Surabaya. Teori behavior menjadi dasar penyerapan awal 
auditor dalam menanggapi regulasi Standar Audit. Dalam hal ini Standar Audit menjadi stimulus yang merangsang auditor untuk mencapai dan memelihara kompetensi.

Kompetensi seorang auditor ditunjukkan dengan keahlian dalam memberikan jasa profesionalnya di mana semakin tinggi kompetensi auditor maka semakin berkualitas audit yang dihasilkan. Untuk menjaga kualitas audit maka Kode Etik Par 130 mengatur auditor untuk memelihara pengetahuan dan keahlian profesional yang dibutuhkan dan menggunakan kemahiran profesionalnya dengan saksama sesuai dengan standar profesi dan kode etik profesi yang berlaku. Untuk dapat melakukan audit secara berkualitas maka diperlukan kompetensi dari seorang auditor agar apa yang dikerjakannya berdasarkan kompetensi yang dimiliki.

Di dalam Kode Etik par. 130.2 kompetensi terbagi menjadi dua yaitu pencapaian kompetensi profesional dan pemeliharaan kompetensi profesional. Untuk pencapaian kompetensi yaitu auditor memulainya dari jenjang karir pertama dengan mencapai minimal Sarjana Ekonomi Akuntansi. Pemeliharaan kompetensi profesional membutuhkan kesadaran dan pemahaman yang berkelanjutan terhadap perkembangan teknis profesi dan perkembangan bisnis yang relevan. Pengembangan dan pendidikan profesional yang berkelanjutan sangat diperlukan untuk meningkatkan dan memelihara kemampuan praktisi agar dapat melaksanakan pekerjaannya secara kompeten dalam lingkungan profesional (Par 130 .3) seperti mengikuti Pendidikan Profesional Berkelanjutan. Hasil penelitian ini sesuai dengan hasil penelitian sebelumnya yang dilakukan oleh Anugerah and Akbar (2014), Agusti and Pertiwi (2013), Kurnia et al. (2014), Karnia and Haryanto (2015) , Gita and Dwirandra (2018) dengan hasil penelitian menunjukkan bahwa kompetensi memiliki pengaruh positif terhadap kualitas audit.

\section{Pengaruh Kompetensi Auditor terhadap Kualitas Audit pada KAP di Surabaya.}

Berdasarkan uji t dengan nilai signifikansi 0,000, maka nilai signifikansi tersebut lebih kecil dari taraf signifikansi 0,05 , dapat disimpulkan bahwa variabel kompetensi terbukti mempunyai pengaruh signifikan terhadap kualitas audit pada KAP di Surabaya. Teori behavior menjadi dasar penyerapan awal auditor dalam menanggapi regulasi Standar Audit. Dalam hal ini Standar Audit menjadi stimulus yang merangsang auditor untuk mencapai dan memelihara kompetensi.

Kompetensi seorang auditor ditunjukkan dengan keahlian dalam memberikan jasa profesionalnya di mana semakin tinggi kompetensi auditor maka semakin berkualitas audit yang dihasilkan. Untuk menjaga kualitas audit maka Kode Etik Par 130 mengatur auditor untuk memelihara pengetahuan dan keahlian profesional yang dibutuhkan dan menggunakan kemahiran profesionalnya dengan saksama sesuai dengan standar profesi dan kode etik profesi yang berlaku. Untuk dapat melakukan audit secara berkualitas maka diperlukan kompetensi dari seorang auditor agar apa yang diker- jakannya berdasarkan kompetensi yang dimiliki.

Di dalam Kode Etik par. 130.2 kompetensi terbagi menjadi dua yaitu pencapaian kompetensi profesional dan pemeliharaan kompetensi profesional. Untuk pencapaian kompetensi yaitu auditor memulainya dari jenjang karir pertama dengan mencapai minimal Sarjana Ekonomi Akuntansi. Pemeliharaan kompetensi profesional membutuhkan kesadaran dan pemahaman yang berkelanjutan terhadap perkembangan teknis profesi dan perkembangan bisnis yang relevan. Pengembangan dan pendidikan profesional yang berkelanjutan sangat diperlukan untuk meningkatkan dan memelihara kemampuan praktisi agar dapat melaksanakan pekerjaannya secara kompeten dalam lingkungan profesional (Par 130 .3) seperti mengikuti Pendidikan Profesional Berkelanjutan. Hasil penelitian ini sesuai dengan hasil penelitian sebelumnya yang dilakukan oleh Anugerah and Akbar (2014), Agusti and Pertiwi (2013) , Kurnia et al. (2014), Karnia and Haryanto (2015) , Gita and Dwirandra (2018) dengan hasil penelitian menunjukkan bahwa kompetensi memiliki pengaruh positif terhadap kualitas audit.

\section{Pengaruh Skeptisisme Profesional terhadap Kualitas Audit pada KAP di Surabaya.}

Berdasarkan uji t dengan nilai signifikansi 0.015, maka nilai signifikansi tersebut lebih kecil dari dari taraf signifikansi 0.05, maka dapat disimpulkan bahwa variabel Skeptisisme Profesional terbukti mempunyai pengaruh signifikan terhadap Kualitas Audit pada KAP di Surabaya.

Semakin tinggi skeptisisme profesional seorang auditor, maka semakin tinggi pula kualitas audit yang dihasilkan. Skeptisisme profesional auditor menunjukkan sikap yang mencakup suatu pikiran yang selalu mempertanyakan, waspada terhadap kondisi yang dapat mengindikasikan kemungkinan kesalahan penyajian, baik yang disebabkan oleh kecurangan maupun kesalahan, dan suatu penilaian penting atas bukti audit. Auditor yang mempunyai sikap skeptis tidak mudah percaya dengan bukti-bukti yang disediakan karena pada umumnya bukti-bukti audit yang disediakan klien merupakan bukti yang bersifat persuasif sehingga auditor harus aktif dalam menerapkan skeptisisme profesionalnya. Hasil penelitian ini didukung oleh penelitian sebelumnya yang dilakukan oleh Anugerah and Akbar (2014).

\section{Skeptisisme profesional memperkuat pengaruh independensi terhadap kualitas audit.}

Berdasarkan uji t dengan nilai signifikansi 0,002, maka nilai signifikansi tersebut lebih kecil dari taraf signifikansi 0,05, dapat disimpulkan bahwa variabel skeptisisme profesional terbukti mampu memoderasi pengaruh independensi terhadap kualitas audit pada KAP di Surabaya secara positif. Artinya 
semakin kuat sikap skeptisisme yang dimiliki oleh auditor, maka semakin kuat pula pengaruh independensi auditor terhadap kualitas audit yang dikerjakannya. Skeptisisme profesional sebagai variabel pemoderasi diperkuat oleh teori behavior. Skeptisisme di sini berposisi sebagai stimulus. Setelah stimulus diterima, maka ia mengerti stimulus ini dan dilanjutkan ke proses berikutnya. Setelah itu seseorang yang menerimanya akan memberi kesediaan sikap untuk bertindak. Akhirnya dengan dukungan fasilitas serta dorongan dari lingkungan maka stimulus tersebut mempunyai efek tindakan dari individu tersebut. Jika dikaitkan dengan independensi, artinya sikap skeptisisme ini akan menjadikan rangsangan serta memberi dampak memperkuat/memperlemah pengaruh independensi terhadap kualitas audit.

Di dalam kasus Garuda Indonesia sebagaimana telah dijabarkan peneliti pada latar belakang, personil KAP sudah seharusnya memiliki sikap skeptis. Adapun hubungannya dengan independensi agar prinsip auditor tidak goyah sehingga tidak akan bekerja sama dengan pihak lain dalam konotasi negatif. Orang yang mempunyai sikap skeptisisme identik dengan kewaspadaan, sehingga menyambung berkaitan dengan independensi yaitu orang yang bersikap independen juga memiliki kewaspadaan. Dengan kata lain dengan adanya mental skeptisisme ini mampu memperkuat sikap independensi seorang auditor. Dalam penelitian yang dihasilkan terlihat jelas bahwa $\mathrm{R}$ square sebelum adanya variabel moderasi sebesar 0,709 dan setelah adanya variabel moderasi berubah menjadi 0,757 . Hal ini tentu menyatakan moderasi dari variabel skeptisisme profesional memperkuat pengaruh dari independensi terhadap kualitas audit.

\section{Skeptisisme profesional memperkuat pengaruh integritas terhadap kualitas audit.} Berdasarkan uji t dengan nilai signifikansi 0,008, maka nilai signifikansi tersebut lebih kecil dari taraf signifikansi 0,05, dapat disimpulkan bahwa variabel skeptisisme profesional terbukti mampu memoderasi pengaruh integritas terhadap kualitas audit pada KAP di Surabaya. Namun nilai koefisien Beta sebesar -0,085 sehingga moderasi yang terjadi merupakan hubungan yang berkebalikan. Artinya jika semakin tinggi skeptisisme maka semakin kecil memoderasi pengaruh integritas terhadap kualitas audit. Begitu juga jika semakin rendah skeptisisme seseroang maka semakin besar dalam memoderasi pengaruh integritas terhadap kualitas audit. Dalam kasus Garuda Indonesia, Kasner sebagai akuntan publik bersikap tidak integritas dengan pengungkapan audit yang tidak terbuka. Hal ini tentu bisa diatasi ketika mental skeptis menempel lekat dalam diri akuntan tersebut.

Hal ini disebabkan karena ketika auditor bersikap waspada, maka cenderung auditor akan bersikap berhati-hati. Namun jika auditor terlalu berhati-hati, hal ini dapat melunturkan sikap integritas sehingga dapat menurunkan kualitas audit. Dari hasil variabel interaksi skeptisisme profesional dengan integritas menghasilkan signifikansi 0,005 namun tidak posi- tif. Auditor yang memiliki skeptisisme tinggi ternyata tidak menjamin saat diinteraksikan dengan integritas untuk memberi peningkatan kualitas audit. Dari hasil penelitian justru menyatakan sebaliknya di mana variabel interaksi Int ${ }^{\star}$ Skep saat rendah akan meningkatkan kualitas audit, atau jika variabel interaksi Int ${ }^{\star}$ Skep saat tinggi akan mengurangi kualitas audit. Auditor yang berintegritas adalah auditor yang memiliki kemampuan untuk mewujudkan apa yang telah diyakini kebenarannya tersebut ke dalam kenyataan dengan nilai-nilai kejujuran. ( IAPI, 2016:Kode Etik par.100.5; Sulaiman (2010)). Ketika seorang auditor berintegritas yang menjunjung nilainilai kejujuran menerapkan mental skeptisisme sebagai pendukung integritas, hal ini justru akan membuat ragu seorang auditor dalam mempertahankan nilai tersebut. Sehingga mental skeptisisme yang diterapkan dipadukan dengan integritas di saat bersamaan justru akan menurunkan kualitas audit.

\section{Skeptisisme profesional memperkuat pengaruh kompetensi terhadap kualitas audit.}

Berdasarkan uji t dengan nilai signifikansi 0,459, maka nilai signifikansi tersebut lebih besar dari taraf signifikansi 0,05, dapat disimpulkan bahwa variabel skeptisisme profesionaltidak mampu memoderasi pengaruh kompetensi terhadap kualitas audit pada KAP di Surabaya. Dengan adanya kompetensi, pada kasus Garuda Indonesia jelas tidak ada alasan atau celah untuk mebuat kesalahan fatal dengan mengungkapkan piutang yang sudah lama beredar menjadi sebuah pendapatan di awal. Skeptisisme akan memperkuat seorang auditor sehingga tidak mudah puas dengan kompetensi yang dimilikinya. Skeptisisme memicu auditor untuk meningkatkan kompetensi auditor.

Tandiontong (2016) mengemukakan bahwa kompetensi masa lalu dengan masa sekarang berbeda di mana kompetensi masa lalu hanya berfokus pada teknik pembukuan, sedangkan kompetensi masa kini auditor diharapkan memiliki kompetensi profesional yang substansial di berbagai area yang saling berkaitan yang berpengaruh terhadap tugas auditnya. Di antara keahlian yang harus dikuasai oleh auditor adalah akuntansi, statistika, komputasi, ekonomika, hukum, manajemen dan kebijakan publik. Untuk mendapatkannya, auditor perlu menempuh jalur pendidikan sesuai dengan kompetensi tersebut, sedangkan sikap untuk meraihnya yakni datang dari apa yang dikemukakan teori Behavior. Terdapat stimulus yang merangsang orang melakukan sesuatu, seperti melihat iklan sebuah Universitas terkemuka di televisi yang menjadikan seseorang calon auditor tergerak untuk menempuh kuliah di Universitas tersebut. Tanpa adanya skeptisisme profesional, seseroang mampu memilih untuk kompetensinya masingmasing, entah kritis atau bahkan tidak kritis sama sekali tidak akan menghalau pilihan seseorang. Sehingga dalam penelitian ini kompetensi tidak mampu dimoderasi oleh skeptisisme profesional dalam pengaruhnya terhadap kualitas audit. 


\section{KESIMPULAN}

Dari hipotesis yang telah diangkat dan diuji oleh peneliti, maka dapat disimpulkan bahwa Independensi berpengaruh positif terhadap kualitas audit. Hal ini menunjukkan bahwa semakin tinggi independensi seseorang maka semakin tinggi pula kualitas audit yang dihasilkan. Integritas berpengaruh positif terhadap kualitas audit. Hal ini menunjukkan bahwa semakin tinggi integritas seseorang maka semakin tinggi pula kualitas audit yang dihasilkan.Kompetensi berpengaruh positif terhadap kualitas audit. Hal ini menunjukkan bahwa semakin tinggi kompetensi seseorang maka semakin tinggi pula kualitas audit yang dihasilkan.Skepstisisme profesional berpengaruh positif terhadap kualitas audit. Hal ini menunjukkan bahwa semakin tinggi skepstisisme seseorang maka semakin tinggi pula kualitas audit yang dihasilkan.Skeptisisme profesional mampu memoderasi pengaruh independensi terhadap kualitas audit. Semakin tinggi skeptisisme seorang auditor, maka akan semakin kuat sikap independensinya sehingga dapat meningkatkan kualitas audit. Skeptisisme profesonal memoderasi pengaruh integritas secara negatif terhadap kualitas audit. Artinya jika interaksi antara skeptisisme dengan integri-

\section{REFERENCES}

Agoes, S. and C, A. I. (2009). Etika Bisnis dan Profesi, and others (ed.) (Jakarta: Salemba Empat).

Agusti, R. and Pertiwi, N. P. (2013). Pengaruh Kompetensi, Independensi dan Profesionalisme terhadap Kualitas Audit (Studi Empiris pada Kantor Akuntan Publik Se Sumatera). Jurnal Ekonomi 21, 3-3.

Anugerah, R. and Akbar, S. H. (2014). Pengaruh Kompetensi, Kompleksitas Tugas dan Skeptisme Profesional terhadap Kualitas Audit. Jurnal Akuntansi 2, 139148.

Arikunto, S. (2014). Penelitian Tindakan Kelas (Jakarta: PT Bumi Aksara).

Febrianti, R. (2014). Pengaruh Independensi, Due Professional Care dan Akuntabilitas Terhadap Kualitas Audit. Jurnal Akuntansi 3.

Ghozali, I. (2011). Aplikasi Analisis Multivariate Dengan Program SPSS, and others (ed.) (Semarang: Badan Penerbit Universitas Diponegoro).

Gita, A. and Dwirandra, A. (2018). Pengaruh Independensi, Kompetensi, Integritas, dan Struktur AuditTerhadap Kualitas Audit Kantor Inspektorat. E-Jurnal Akuntansi Universitas Udayana 25.

Hartono, J. (2013). Metodologi Penelitian Bisnis: Salah Kaprah dan PengalamanPengalaman (Yogyakarta: BPFE)

Hasan, M. I. (2002). Pokok-pokok Materi Metodologi Penelitian dan Aplikasinya. In Ghalia Indonesia.

Herry (2010). Potret Profesi Audit Internal (Di Perusahaan Swasta \& BUMN Terkemuka) (Bandung: Alfabeta).

Indonesia, I. A. P. (2016). Standar Audit 200 tentang Tujuan Keseluruhan Auditor Independen dan Pelaksanaan Audit Berdasarkan Standar Audit, and others (ed.) (Jakarta: Salemba Empat).

Karnia, N. D. and Haryanto (2015). Pengaruh Kompetensi, Independensi, Motivasi, danAkuntabilitas terhadap Kualitas Audit 4, 2337-3806.

Kurnia, W., Khomsiyah, K., and Sofie, S. (2014). Pengaruh Kompetensi, Independensi, Tekanan Waktu dan Etika Auditor terhadap Kualitas Audit. Jurnal Akuntansi Trisakti 1, 49-67. doi: 10.25105/jat.v1i2.4826.

Malhotra (2005). Riset Penelitian, and others (ed.) (Jakarta: Gramedia Pustaka Utama).

Mulyadi (2017). Auditing Buku 1 Edisi 6, and others (ed.) (Jakarta: Salemba Empat). tas naik justru akan menurunkan kualitas audit. Hal ini disebabkan ketika auditor menjunjung nilai-nilai kejujuran dan di saat bersamaan auditor mengeluarkan sikap skeptis maka akan menimbulkan suatu keraguan sehingga akan menurunkan kualitas audit. Skeptisisme profesional tidak mampu memoderasi pengaruh kompetensi terhadap kualitas audit. Hal ini disebabkan karena kompetensi merupakan pilihan sehingga tidak membutuhkan sikap skeptisisme profesional dalam memperkuat atau memperlemah kompetensi terhadap kualitas audit.

\section{PENDANAAN}

Penelitian ini dilakukan dengan pendanaan mandiri dari peneliti.

\section{UCAPAN TERIMA KASIH}

Peneliti mengucapkan terima kasih kepada semua pihak atas partisipasinya dan membantu hingga terselesaikannya penelitian ini dengan baik dan lancar.

Sari, N. N. (2011). Pengaruh Pengalaman kerja, Independensi, Objektivitas, Integritas, Kompetensi dan Etika terhadap Kualitas Audit.Skripsi. Program Sarjana Fakultas Ekonomi Universitas Diponegoro (Semarang).

Sendjaja, S. D. (2004). Teori Komunikasi (Jakarta: Universitas Terbuka).

Sugiyono (2018). Metode Penelitian Kuantitatif, and others (ed.) (Bandung: Alfabeta).

Suhayati, E. and Rahayu, S. K. (2010). Auditing, Konsep Dasar dan Pedoman Pemeriksaan Akuntan Publik. In Graha Ilmu.

Sujarweni, V. W. (2014). Metode Penelitian: Lengkap, Praktis dan Mudah Dipahami (Yogyakarta: Pustaka Baru Press).

Sukriah, I., Akram, and Inapty, B. A. (2009). Pengaruh Pengalaman Kerja, Independensi, Obyektifitas, Integritas, dan Kompetensi Terhadap Kualitas Hasil Audit (Palembang: Simposium Nasional Akuntansi XII).

Sulaiman, A. S. (2010). The Quantum Success, and others (ed.) (Jakarta: PT Elex Media Komputindo).

Susanti and Tarigan (2013). Pengaruh Kompetensi, Etika dan Fee Audit Terhadap Kualitas Audit. Jurnal Akuntansi, Vol. 13 No.1 13.

Susilo and Widyastuti (2015). Integritas, Objektivitas, Profesionalisme Auditor dan Kualitas Audit di Kantor Akuntan Publik Jakarta Selatan. Jurnal Riset Akuntansi dan Perpajakan 2, 65-77.

Tandiontong, M. (2016). Kualitas Audit dan Pengukurannya (Bandung: Alfabeta).

Tuanakotta, T. M. (2013). Audit Berbasis ISA (Jakarta: Salemba Empat).

Conflict of Interest Statement: The authors declare that the research was conducted in the absence of any commercial or financial relationships that could be construed as a potential conflict of interest.

Copyright (c) 2020 Santoso, Riharjo and. This is an open-access article distributed under the terms of the Creative Commons Attribution License (CC BY). The use, distribution or reproduction in other forums is permitted, provided the original author(s) and the copyright owner(s) are credited and that the original publication in this journal is cited, in accordance with accepted academic practice. No use, distribution or reproduction is permitted which does not comply with these terms. 


\section{LIST OF TABLES}

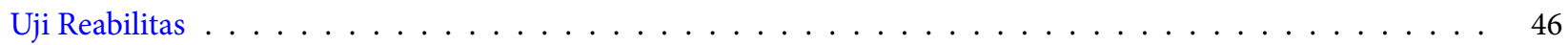

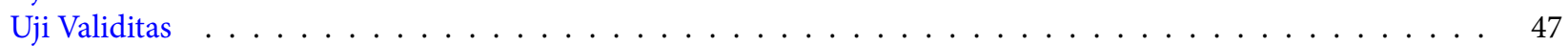

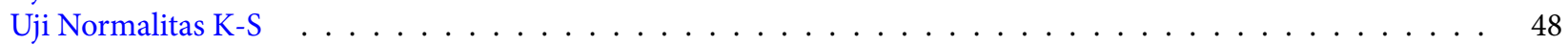

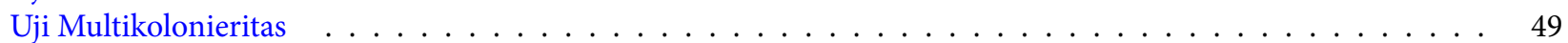

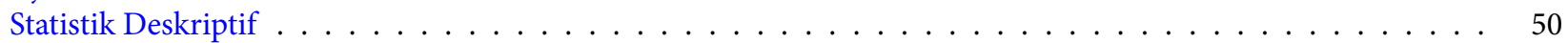

Uji F pada Model Regresi $1 \ldots \ldots \ldots 1$

Uji F pada Model Regresi $2 \ldots \ldots . \ldots . \ldots$

Uji t Model Regresi $1 \ldots \ldots \ldots$

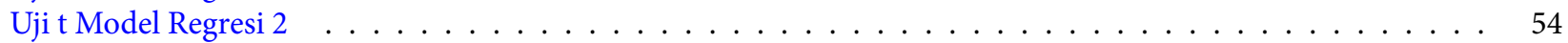


TABLE 1 | Uji Reabilitas

\begin{tabular}{llll}
\hline Variabel & Nilai cronbachs alpha & Nilai Kritis & Keterangan \\
\hline Skep & 0.688 & 0.6 & Reliabel \\
Ind & 0.722 & 0.6 & Reliabel \\
Int & 0.801 & 0.6 & Reliabel \\
Kom & 0.766 & 0.6 & Reliabel \\
KA & 0.770 & 0.6 & Reliabel \\
\hline
\end{tabular}


TABLE 2 | Uji Validitas

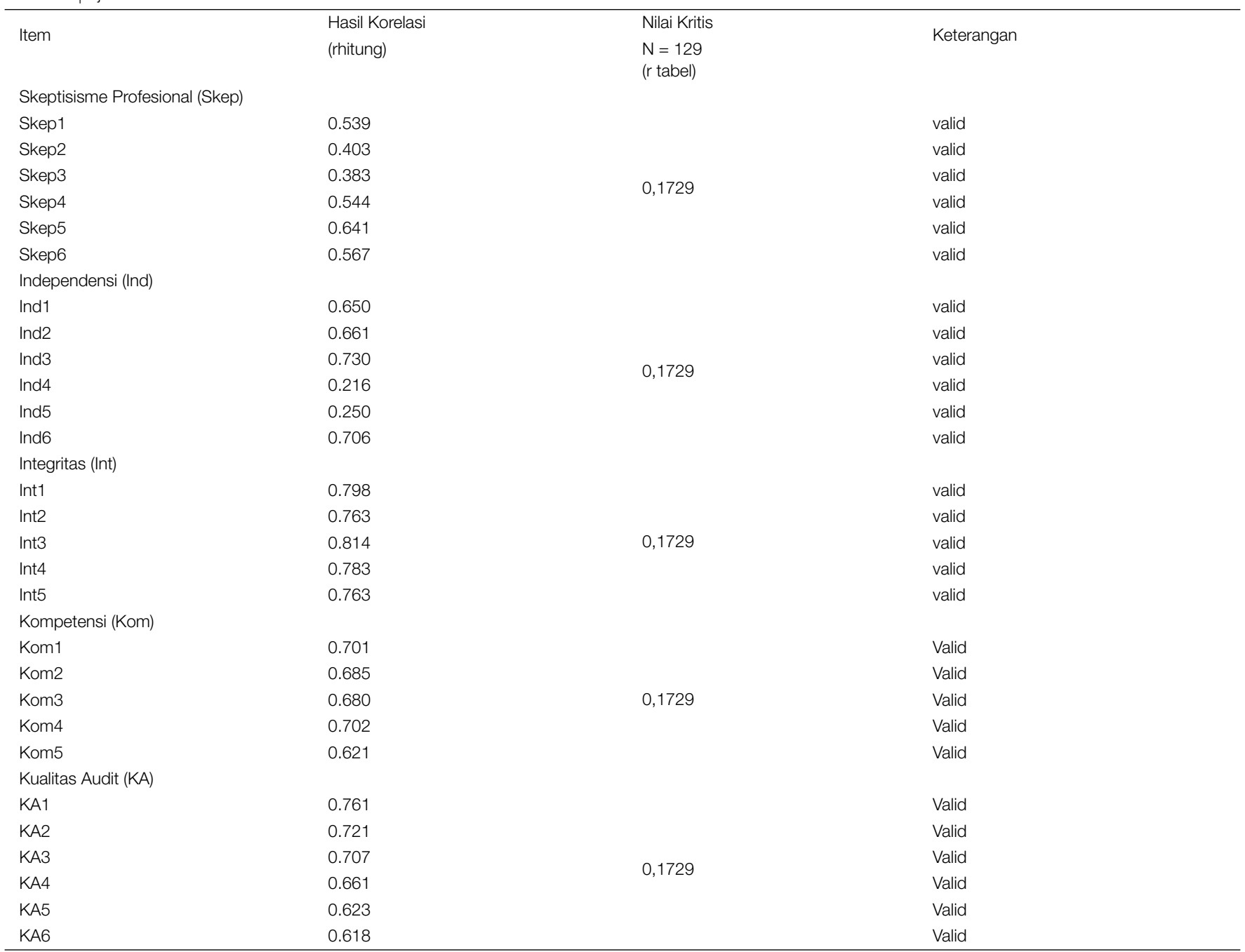


TABLE 3 | Uji Normalitas K-S

\begin{tabular}{ll}
\hline \multicolumn{2}{l}{ One-Sample Kolmogorov-Smirnov Test } \\
& Unstandardized Residual \\
$\mathrm{N}$ & 129 \\
Normanean & .0000000 \\
Paramterebiation & 1.31352265 \\
Most Absolute & .046 \\
Extrentive & .045 \\
Differenegrative & -.046 \\
Test Statistic & .046 \\
Asymp. Sig. (2- & $.200 \mathrm{c}, \mathrm{d}$ \\
tailed) & \\
\hline
\end{tabular}


TABLE 4 | Uji Multikolonieritas

Variabel
Independensi
Integritas
Kompetensi
Skeptisisme Profesional

Tollerance

0.551

0.566

0.420

0.944
VIF

1.814

1.766

2.382

1.060
Keterangan

Tidak terjadi multikolonieritas

Tidak terjadi multikolonieritas

Tidak terjadi multikolonieritas

Tidak terjadi multikolonieritas 
TABLE 5 | Statistik Deskriptif

\begin{tabular}{llllll}
\hline & N & Minimum & Maximum & Mean & Std. Deviation \\
& Statistic & Statistic & Statistic & Statistic & Statistic \\
KA & 129 & 15.00 & 28.00 & 23.6899 & 2.49624 \\
Ind & 129 & 10.00 & 22.00 & 18.5969 & 1.90607 \\
Int & 129 & 11.00 & 24.00 & 19.2558 & 2.29905 \\
Kom & 129 & 11.00 & 24.00 & 18.9070 & 2.13029 \\
Skep & 129 & 20.00 & 29.00 & 23.9767 & 1.69312 \\
Valid N (listwise) & 129 & & & & \\
\hline
\end{tabular}


TABLE 6 | Uji F pada Model Regresi 1

\begin{tabular}{|c|c|c|c|c|c|c|}
\hline \multicolumn{2}{|c|}{ Model } & Sum of Squares & df & Mean Square & $\mathrm{F}$ & Sig. \\
\hline & Regression & 565.859 & 3 & 188.620 & 101.742 & $.000 \mathrm{~b}$ \\
\hline \multirow[t]{2}{*}{1} & Residual & 231.737 & 125 & 1.854 & & \\
\hline & Total & 797.597 & 128 & & & \\
\hline \multicolumn{7}{|c|}{ Sumber: Output SPSS } \\
\hline
\end{tabular}


TABLE 7 | Uji F pada Model Regresi 2

\begin{tabular}{llllll}
\hline \multicolumn{1}{c}{ Model } & Sum of Squares & df & Mean Square & F & Sig. \\
\multicolumn{1}{l}{ Regression } & 603.475 & 7 & 86.211 & 53.737 & $.000 \mathrm{~b}$ \\
$\quad$ Residual & 194.122 & 121 & 1.604 & & \\
$\quad$ Total & 797.597 & 128 & & & \\
\multicolumn{2}{l}{ Sumber: Output SPSS } & & & & \\
\hline
\end{tabular}


TABLE 8 | Uji t Model Regresi 1

\begin{tabular}{|c|c|c|c|c|c|c|}
\hline \multicolumn{2}{|c|}{ Model } & \multicolumn{2}{|c|}{$\begin{array}{l}\text { Unstandardized } \\
\text { Coefficients }\end{array}$} & \multirow{2}{*}{$\begin{array}{l}\text { Standardized Coefficients } \\
\text { Beta }\end{array}$} & \multirow[t]{2}{*}{$t$} & \multirow[t]{2}{*}{ Sig. } \\
\hline \multirow{6}{*}{1} & & $B$ & Std. Error & & & \\
\hline & (Constant) & 1.943 & 1.291 & & 1.505 & .135 \\
\hline & Ind & .448 & .085 & .342 & 5.277 & .000 \\
\hline & Int & .147 & .069 & .136 & 2.138 & .034 \\
\hline & Kom & .559 & .087 & .477 & 6.440 & .000 \\
\hline & Skep & .177 & .072 & .120 & 2.473 & .015 \\
\hline
\end{tabular}


TABLE 9 | Uji t Model Regresi 2

\begin{tabular}{|c|c|c|c|c|c|c|}
\hline \multicolumn{2}{|c|}{ Model } & \multicolumn{2}{|c|}{$\begin{array}{l}\text { Unstandardized } \\
\text { Coefficients }\end{array}$} & \multirow{2}{*}{$\begin{array}{l}\text { Standardized Coefficients } \\
\text { Beta }\end{array}$} & \multirow[t]{2}{*}{$\mathrm{t}$} & \multirow[t]{2}{*}{ Sig. } \\
\hline & & B & Std. Error & & & \\
\hline \multirow{8}{*}{1} & (Constant) & 19.463 & 12.813 & & 1.519 & .131 \\
\hline & Ind & -3.723 & 1.310 & -2.843 & -2.843 & .005 \\
\hline & Int & 2.180 & .767 & 2.008 & 2.841 & .005 \\
\hline & Kom & 1.466 & 1.229 & 1.251 & 1.193 & .235 \\
\hline & Skep & -.686 & .503 & -.465 & -1.364 & .175 \\
\hline & Ind_Skep & .172 & .054 & 4.076 & 3.192 & .002 \\
\hline & Int_Skep & -.085 & .031 & -2.428 & -2.706 & .008 \\
\hline & Kom_Skep & -.038 & .051 & -1.012 & -.743 & .459 \\
\hline
\end{tabular}




\section{LIST OF FIGURES}

$1 \quad$ Uji Heterokedastisitas 


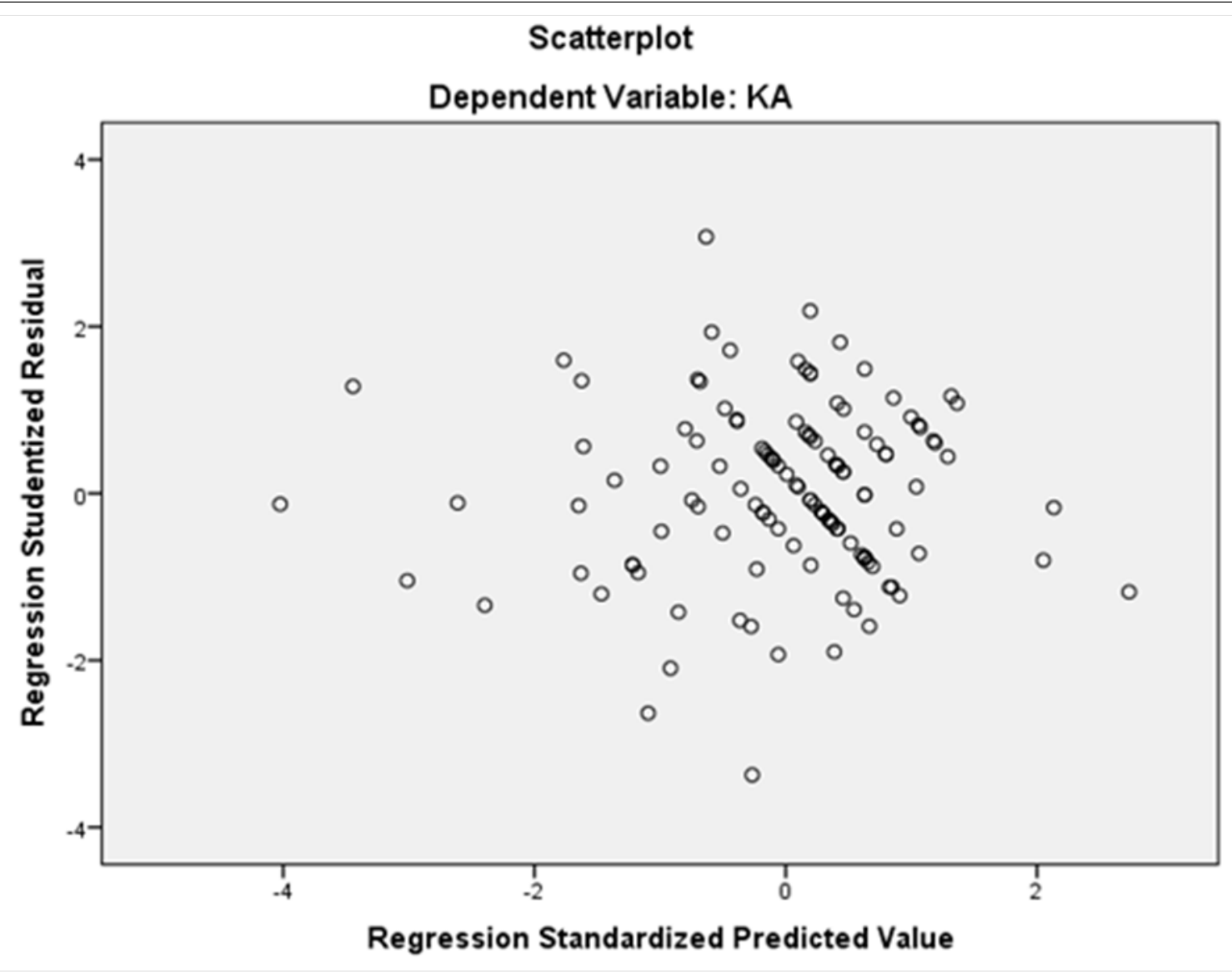

FIGURE 1 | Uji Heterokedastisitas 